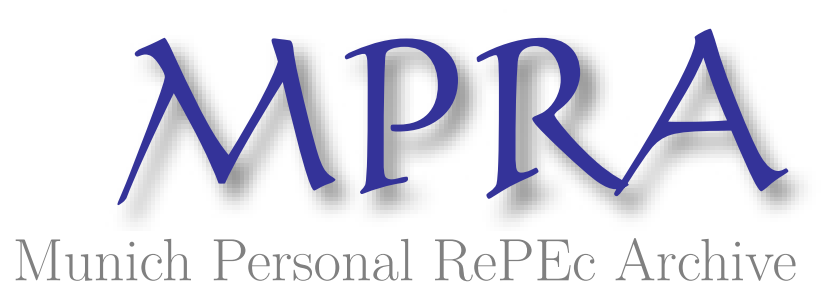

\title{
Diversification into Technical Textiles: A Forward Momentum for Indian Textiles Industry
}

Chugan, Pawan Kumar

Nirma University - Institute of Management

December 2011

Online at https://mpra.ub.uni-muenchen.de/55050/

MPRA Paper No. 55050, posted 09 Apr 2014 19:42 UTC 


\section{Diversification into Technical Textiles: A Forward Momentum for Indian Textile Industry}

Pawan Kumar Chugan*

* Faculty, Institute of

Management, Nirma

University, Ahmedabad
Over several centuries the textile industry in India has grown from a cottage industry to a well organized industry. One of the oldest industries of the country, it is also the second largest employer after agriculture. It generates employment opportunities for approximately 33.17 million workers directly and 54.85 million workers indirectly. India possesses competitive advantages in production and export of textiles and clothing and it was envisaged that the end of the quota regime (phasing out the Multifibre Arrangements on January 1, 2005) will provide it several opportunities for growth.

While the end of quota-based curbs offered the Indian textile industry growth opportunities, they lasted only for a short period and the industry in the last few years has been continuously witnessing turbulent times with declining growth. The industry is losing its competitiveness to other cheaper sourcing countries. The recent global recession has further worsened the scenario resulting in loss of many jobs.

Thus, to prop up the textile and clothing industry, it is essential not only to improve the efficiency and quality of output and recapture the losing market share but 
also to look at new markets, new products, and new opportunities simultaneously. Technical textiles are a promising area of diversification for domestic and export markets. India is one of the global leaders in technical textiles and clothing (Chugan, 2011). An attempt has been made below to describe the salient features of technical textiles vis-à-vis opportunities for the Indian textile industry.

\section{Turbulences in Indian Textile Industry}

Until the recession took over, it was a doorsill of growth. The Indian textile industry, one of the world's best performing industries, is now on a downtrend. Industry analysts had predicted that by the end of April 2009, approximately half a million direct workers from textile, garment, and handicraft sectors could have lost their jobs. Considering other people who were indirectly associated with the industry, total direct and indirect job loss is expected to reach 6 million. ${ }^{1}$

In fact, the turbulent time for the industry had begun with the termination of the WTO agreement on textiles and clothing in 2005. With the removal of the quota regime, the industry started facing tough competition from other countries leading to slowdown in exports in subsequent years (Chugan, 2011). According to PCL (2010) after the termination of the Multifibre Arrangements (MFAs), exports of textiles and clothing took a giant leap in 2005-6 and reached US $\$ 17.5$ billion, an increase of about 25 per cent over the previous financial year. However, this momentum could not be maintained in 2006-7 and exports managed to reach US \$ 18.73 billion, registering a growth of just about 7 per cent over 20056 , falling short of the targeted US $\$ 19.73$ billion by about 5 per cent. According to FICCI (2008), the growth rate in textile exports which was 21 per cent in 2005-6, fell significantly in the following year to almost 6 per cent, and was 10 per cent in 2007-8. The weakening of demand in major destinations like USA and EU has led to low growth in exports. Citing the example of Ludhiana city in Punjab, Thakurta (2009) states that some of the city's major garment making companies, which had created 400,00o jobs in Ludhiana alone, had suffered more than 50 per cent loss in sales, specifically exports.

Further, smaller countries such as Vietnam, Bangladesh, and Pakistan have wrested the advantage in textile and clothing exports from India, raising their exports to markets like the US and EU in the post-quota years (2005-7). India's share in EU textile imports declined from 7.9 per cent to 7.5 per cent between 1995 and 2007. There has, however, been a

\footnotetext{
1 "Recession Cannibalizes More Indian Textile Jobs" http://www.fibre2fashion.com/industryarticle/17/1658/ recession-cannibalizes-more-indian-textile-jobs1.asp , accessed on February 4, 2011.
} 
declining trend in growth of India's textile and clothing exports to EU since 2005. Similarly, in the US market, India's average price for textile exports declined in the post-quota period, but was still higher than China and Pakistan prices (FICCI, 2008). The situation on the export front remained poor for the next four years. ${ }^{2}$ Exports to US declined to US \$4430 million from US\$ 4752 million. Similarly, exports to Canada declined to US\$ 351 million from US\$ 406 million. This change has taken place in spite of overall increase in exports from US\$ 19,436 million to US\$ 23,419 million. Exports to major European destination, such as UK, Germany, France, Spain, Turkey, the Netherlands, Belgium, and Denmark have declined because of recent European crisis (Chugan and Rawani, 2012). According to Mehta (2011), consumer confidence is low at this moment and retailers fear an impending slowdown. Therefore, while adopting a very cautious approach, the Indian textile industry has now started targeting countries such as Russia, Japan, Latin America, and Australia which are very strong markets for China as well. ${ }^{3}$

According to the China Daily (2009), the economic meltdown in the major export markets of Europe and US has led to a substantial fall in foreign orders and could be the final nail in the coffin for many of India's small and medium sized textile houses. Citing an example of a unit in Noida the report states that the colourful organza curtains, floor cushions, and quilt covers that were once produced in bulk are piled high on the tables.

\section{Global Recession to Recovery vs. Textiles Industry}

The impact of global recession was not felt by all industries; rather some were more badly affected than others. According to Thakurta (2009) while the Indian economy was relatively insulated from the international financial crisis, one particular sector that was badly hit was the textiles and garments manufacturing industry. At least 1.2 million workers in this industry were expected to be without jobs by the end of March 2009. Moreover, the economic stimulus package announced by the government in 2008 also failed to cheer the industry, since it did not address all the major issues.

According to Assocham (2010), while the Indian economy may be showing signs of recovery in some sectors such as cement and steel, the textile sector continues to be in the doldrums with millions of workers jobless, and export orders not picking up as demand continues to be

2 Official India Textile Statistics 2009-10, bttp://www.txcindia.com/html/comp\%2otable\%2opdf \%202009-10/T 120\%20EXPORT\%20OF\%20ALL\%20TEXTILE\%2OITEMS\%20IN\%20VALUE\%20 TRMS\%2OMAJOR\%20COUNTRIES.pdf, accessed on October 1, 2011.

${ }^{3}$ Chinese penetration in Australian and Japanese markets is 90\%, yet India knows it needs to take a plunge. (Mehta, 2011). 
low in US and developed markets. This sector, which is the second major employer in India after agriculture, providing employment to 91 million people and contributing about 13 per cent in export earnings and 4 per cent in India's GDP, is still suffering the heat of global slowdown as indicated by declining exports and massive layoffs. According to FMAG (2009) the credit quality of Indian textile companies has weakened considerably since the beginning of the financial year 2009, spurring rating actions ranging from outlook revisions to multiple-notch downgrades. According to a new report by Fitch Ratings, the Indian textile sector remains highly vulnerable to global recession owing to its huge dependence on exports.

In this scenario of dwindling exports, technical textiles are an important area which has great potential for diversification and upgradation of the industry because conventional textiles and clothing have reached saturation levels in terms of product development, diversification, value addition, etc. and are subject to severe global competition. Technical textiles, on the other hand, offer great opportunities not only in different parts of the world, but in the domestic market as well. In the quota free regime, it is becoming extremely difficult to compete in the world and grab a higher share in consumer textiles, garments; now is the right time to look into the diversification of value added textile products (technical textiles) (Chugan, 2007).

\section{Technical Textiles: Definition and History}

Broadly speaking, the textile industry may be classified into tradition textiles and technical textiles. In general, the textile industry provides textile materials primarily for apparels. This segment is known as traditional textiles as it fulfills the basic needs of human beings. As a result of ever increasing human demand, the textile industry has also moulded itself with new technological developments for more specific needs and the newer materials are used in many more areas such as medicine, sports, defence, construction, agriculture, home decoration, industry, transport, electrical and electronics, etc. The newer materials are now more popularly known as technical textiles. Further with better research and development, technical textiles have been given an aesthetic appeal as well.

Technical textiles came into the peak as soon as the manmade fibre was discovered around 1900. Simultaneously new technologies such as special weaving processes, nonwoven techniques, etc. were developed to manufacture technical textiles. The world has observed 
fast growth in fibre production having very distinguishing characteristics such as high resistance to temperature, stable under stress and strain, strong enough to absorb impact of highly reactive chemicals, etc. All these efforts have led to widespread use and growth of technical textiles. ${ }^{4}$ Technical textiles are classified into twelve categories as shown in Table 2.

Technical textiles are often considered nonwovens. However, as Sheshadri (2009), points out, not all technical textiles are nonwovens. Nonwoven technology is a manufacturing process of developing fabrics directly from fibres by skipping intermediary processes such as spinning, winding, weaving, etc. Technical textiles can be manufactured using conventional manufacturing processes such as weaving, braiding, and knitting as well as nonwoven technologies. As of today, nonwovens have penetrated highly into disposable sectors where aesthetic aspects are not of primary importance. The value addition to nonwovens and technical textiles comes from the functional properties they provide such as body fluid absorbency in the case of diapers, fluid repulsion in the case of medical garments, and softness and resiliency in the case of high-loft upholstery products. Depending on the type of end-use requirements and economics, different available nonwoven and conventional technologies are selected to develop particular technical textile products. A good example is the use of spunlacing technology to develop lightweight disposable wipes. Sheshadri (2011) feels that the categorization of nascent Indian technical textiles into 12 segments as in Table 2 is premature and will cause confusion. There are several products that can fit well in many segments and such a categorization for an emerging market may not be suitable. In order to have an easier and useful segmentation from the point of view of marketing, he has proposed a three way classification:

- Consumer Products

- Institutional Products

- Government Procurement Products

ICRA (2009) is of the opinion that technical textiles could be classified as core technical and non-core technical textiles. Core technical textiles should comprise specially designed and engineered textiles that are used in high-tech products and processes and require advanced manufacturing technology.

\footnotetext{
${ }^{4}$ Technical Textiles Overview, http://www.technicaltextile.net/about-technical-textile.aspx, accessed on March 21,2011
} 


\section{Diversification into Technical Textiles}

The industry and the government have recognized the potential of technical textiles as the growth engine. This is one of the very few sectors of the textile industry that is growing at a very fast pace, especially in the Asian region. However, in India, investments in this sector continue to remain low (Mital, Swaminathan, and Dogra 2005). Indian has a potential to garner up to a 10 per cent share of the global market in the area of technical textiles, provided substantial investments are made (Chugan, 2005, 2006).

Traditional textiles today are unable to cope with the cost of production for various reasons like fast technological obsolescence, high cost of modernization, power, etc. The present product mix of traditional textiles is not remunerative and, therefore, more and more ideas of value addition to textile products are gaining momentum. Technical textiles, in this context, are just perfect (Arup, Hira, and Gangopadhyay, 2007). Further, it has been well established that the consumption pattern of technical textiles is positively and directly related with the growth of per capita income. India's technical textiles sector will grow at rate of over 13 per cent. Since, the target of India's textile industry is set about $\$ 150$ billion by 2015, technical textiles are set to reach $\$ 15$ billion assuming that they account for at least 10 per cent of the textile industry's share.

Unlike the conventional textiles industry which is highly export oriented, technical textiles, in general, are import intensive as many of the products such as baby diapers, adult diapers, polypropylene spunbond fabrics for disposables, wipes, protective clothing, hoses, webbings for seat belts, etc. are imported. There is vast scope for manufacturing many of these products in the country. According to Ghosal (2010) India imports technical textiles worth Rs. 4000 crore predominantly from China, Malaysia, Hong Kong, Thailand, Germany, and Italy. ICRA (2009) states that core technical textiles are fairly import intensive with around 26 per cent of the domestic demand being met by imports. Some of the products like technical textile component of baby diapers, incontinence diapers, high altitude clothing, etc. are majorly imported with imports accounting for over 90 per cent of domestic consumption. In the case of technology intensive products such as incontinence diapers, high altitude clothing, artificial turf, etc. lack of manufacturing technology for these products and lack of availability of raw materials are the primary reasons for the high level of imports.

Sheshadri and Appachi (2010) have made estimates of consumption of nonwoven textiles with reference to the growth in GDP per capita for the period 2005 to 2050 (see Table I). India's nonwoven and technical textile industry will grow twice as fast as the growth of the current developed markets during its growth phase. Although India's industry base is 
extremely small currently with an annual production of 60,000 tonnes, the next two decades are set to change the nature of the Indian technical textile industry and provide ample growth opportunities.

\section{Table 1: Consumption of Nonwovens in India vs. GDP Per Capita}

\begin{tabular}{|c|c|c|}
\hline & $\begin{array}{c}\text { GDP per capita } \\
\text { (US\$) }\end{array}$ & $\begin{array}{c}\text { Consumption } \\
\text { of Nonwovens } \\
\text { (kg) }\end{array}$ \\
\hline 2005 & 733 & 0.08 \\
\hline 2010 & 1375 & 0.21 \\
\hline 2015 & 2564 & 0.40 \\
\hline 2020 & 4780 & 0.75 \\
\hline 2025 & 8913 & 1.39 \\
\hline 2030 & 16618 & 2.59 \\
\hline 2035 & 30985 & 4.79 \\
\hline 2040 & 57773 & 8.90 \\
\hline 2045 & 107720 & 16.57 \\
\hline 2050 & 200850 & 36.14 \\
\hline
\end{tabular}

*Assuming an increase of 13.27 per cent in per capita every year per capita GDP Source: World Bank

Not only in developed countries of the world such as US, European Union, Japan, and Australia, but also in many developing countries of Asia there is great potential for technical textiles. According to ICRA (2009) the technical textile industry has immense potential in developing countries. Asia is now emerging as a powerhouse of both production and end-use consumption of technical textiles. China, Japan, Korea, Taiwan, and other developing countries, particularly India, have great potential to make an impact in this industry in the coming decade. The demand for technical textiles will be boosted by the changing economic scenario in these countries. Considering its highly skilled and scientific/technical manpower and abundant availability of raw materials, India can emerge as a key player in the technical textiles industry. 


\section{Opportunities in Technical Textiles}

The global market for technical textiles is presently about US $\$ 160$ billion whereas India's share of consumption is about US $\$ 6$ billion only.

India's GDP is set to grow in a range of 8 to 9 per cent. As the consumption of technical textiles is positively correlated with rising income, demand will increase considerably in the years to come. It is estimated (Sheshadri, 2008) that the Indian economy may exceed that of Europe and Japan by 2030 and of the United States by 2045, because of the increase in household income and the predicted growth in agriculture, manufacturing, and services sectors. The economy has been receiving boost because of a growing middle class and young and educated population. These are the vital factors for the growth of nonwoven and technical textiles in the country. India's per capita consumption of nonwovens and technical textiles would double that of US when the country reaches a per capita GDP of US $\$ 45,028$.

The scope for growth is tremendous as the current per capita consumption is quite low at 0.3 $\mathrm{kg}$ as against of 7-10 $\mathrm{kg}$ in the developed world. China's per capita consumption is $1.7 \mathrm{~kg}$. Even among the overall textile industry, the share of technical textiles in India at 5 per cent does not compare well with the corresponding figure of 30 per cent as reported in the developed world (Kannan, 2008). Hence, there exists huge untapped potential.

There exists good scope for diversification in all the 12 categories of technical textiles. The data compiled by ICRA for domestic consumption and market size for the year 2007-8 and projections for 2012-13 are given in Table 2.

India's infrastructure development story is well known. This sector which was neglected after independence is now the cynosure of all eyes and huge investments have been planned. This is expected to result in the growth of geotech and buildtech, i.e. application of textiles in construction activities such as roads, airports, dams, railways, logistics/supply chain, sea erosion control, and solid waste management systems. Some of the products under the buildtech category are hoardings and signage, scaffolding nets, awnings and canopies, tarpaulins, architectural membranes, roofing materials, etc.

Indigenization of technical textiles (import substitution) will not only contain imports and achieve strategic self-sufficiency in sensitive and emerging areas of applications like defence, aerospace, waste management, etc. but also provide new avenues for value added exports. Promoting technical textiles as a tool of value addition for survival and revival of the Indian textile industry holds a high potential of success (Arup, Hira, and Gangopadhyay, 2007). 
Table 2: Domestic Consumption and Market Size of Technical Textiles

\begin{tabular}{|l|r|r|r|r|}
\hline \multicolumn{2}{|c|}{ Domestic Consumption (Rs crore) } & \multicolumn{2}{c|}{ Market Size (Rs crore) } \\
\hline \multicolumn{2}{|c|}{ 2007- o8 (E) } & $\mathbf{2 0 1 2 - 1 3 ~ ( P )}$ & $\mathbf{2 0 0 7 - 0 8 ~ ( E ) ~}$ & $\mathbf{2 0 1 2}-\mathbf{1 3}$ (P) \\
\hline Agrotech & 487 & 709 & 553 & 811 \\
\hline Meditech & 1,514 & 2,263 & 1,669 & 2,490 \\
\hline Mobiltech & 3,161 & 5,137 & 3,183 & 5,166 \\
\hline Packtech & 14,067 & 25,913 & 14,630 & 26,753 \\
\hline Sportech & 2,632 & 4,358 & 2,851 & 4,761 \\
\hline Buildtech & 1,726 & 2,655 & 2,157 & 3,232 \\
\hline Clothtech & 6,570 & 9,665 & 6,908 & 10,225 \\
\hline Hometech & 4,791 & 8,420 & 5,025 & 8,748 \\
\hline Protech & 1,259 & 2,021 & 1,302 & 2,075 \\
\hline Geotech & 185 & 326 & 272 & 454 \\
\hline Oekotech* & 68 & 160 & 68 & 160 \\
\hline Indutech & 2,443 & 4,255 & 3,206 & 5,437 \\
\hline Total & 38,835 & 65,722 & 41,756 & 70,151 \\
\hline
\end{tabular}

Market size includes domestic consumption and exports.

*Oekotech size has been included as a part of Geotech.

Source: ICRA, 2009.

The defence segment is one of the largest consumers of protech clothing such as bullet-proof jackets and high altitude clothing. Further, protective textiles also include garment and accessories to protect people from dangerous or hazardous materials and process during their job as well as leisure activities. Sleeping systems, parachutes, weapon rolls, army tents, blankets, fabrics with waterproof and breathable membrane, mountain safety ropes, special jackets for fire/bullet protection, disposable garments and gears against harmful chemicals, gases and pesticides, etc. are included in this category.

Modernization of Indian agriculture is taking place with the use of advanced techniques of production and technologies with due attention to productivity, quality improvement, preservation of food stocks, packaging, etc. Thus, agrotech is another area which has great potential. It includes products such as shade-nets, mulchmats, crop-covers, anti-hail nets, bird protection nets, and fishing nets.

The Indian automobile industry is getting modernized and application of textiles in areas of shipbuilding, aerospace, rail vehicles, motorcycles bikes, airbags, tyres, etc. has gone up 
substantially. Today, a car utilizes at least $15 \mathrm{~kg}$. of textile materials. Thus mobiltech with special features such as sound absorbency, UV resistance, bursting resistance, degradation resistance, etc. have huge potential for both domestic and export markets.

The meditech segment includes products such as diapers, sanitary napkins, surgical dressings, artificial implants, and other miscellaneous products of hygiene, health, and personal care which are available in woven, nonwoven, and knitted forms. Further, with the government laying emphasis on promoting rural healthcare, this area offers tremendous scope.

With the growing awareness for environment protection, application of textiles in areas such as waste disposal and recycling is opening up new opportunities. Some of the products manufactured under this segment are soil seals, textile drainage systems, mobile containers, textile noise barrier systems, landfill textiles, erosion prevention systems, etc. Thus, ecotextiles categorized as oekotech offer steady and growing opportunities for diversification.

The revolutionary new textiles used in the sports and leisure industry are popularly known as sportech. Today's sports demand high performance equipment and apparel. The light weight and safety features of sportech have become important in their substitution for other materials. These high-functional and smart textiles are increasingly adding value to the sports and leisure industry by combining utilitarian functions with wearing comfort that leads to achieving high level of performance $(\mathrm{BCH}, 2011)$. This segment includes products such as sports composites, parachute fabrics, sports shoe components, swim wear, etc. Further, artificial turf, a substitute for natural grass, is being used extensively in stadiums and has special characteristics such as pile fibres which are non-harsh and soft to feel, backing clothing, shock absorbing foam, and supporting base. According to technical textiles.net ${ }^{5}$ in India the market size for it has increased by 20 per cent to account for usage in landscaping. Demand for artificial turfs / synthetic tracks is likely to double in the next five years as a result of government focus on developing the sports infrastructure. The Indian artificial turf market size is expected to increase from $140 \mathrm{mt}$ (Rs. 26 crore) in 2007-8 to around $280 \mathrm{mt}$ (Rs.52 crore) by 2012-13.

Packtech is the largest segment amongst technical textiles with market size estimated to touch Rs. 26,753 crore in 2012-13. As the demand for packaging and packing material is directly related to production and overall economic growth vis-à-vis growing movement of goods for domestic and international trade, this segment has a very promising market.

\footnotetext{
${ }^{5}$ For more details, see “Artificial Turf the New Face of Sports Textiles," http://www.technicaltextile.net /articles/ajax/printarticle.asp?article_id=3236\&page, accessed on March 25, 2011.
} 
Further, with the growing concern of environmental protection the need for reusable packages and containers is opening new opportunities for textile products in this market. Packtech includes heavyweight, dense woven fabrics (used for bags, sacks, flexible intermediate bulk carriers, and wrappings for textile bales and carpets), lightweight nonwovens used as durable papers, tea bags, and other food and industrial product wrappings. The use of textile materials in consumer packaging is exhibited in products like FIBC big bags (Flexible Intermediate Bulk Containers) for powdered and granular materials; laundry bags and other bulk packaging products; sacks for storage etc.; twine and string for tying packages, etc (excludes agricultural applications); non-paper tea bags and coffee filters; food soaker pads; net packaging for storing, packing, transporting, retailing, foodstuffs, and toys; woven fibre strapping, lightweight mailbags; soft luggage, etc.

Industrialization and growing production of sophisticated products are throwing up new markets for technical textiles. Technical textile items known as indutech have diverse applications in almost all industries. Some of the popular applications include filtration (filters), conveying (conveyor belts), cleaning with special absorption capacities, polishing cloths, sealing cords for tunnel oven dollies, coated/laminated fabrics, heat resistant fibres/yarns, etc.

With growing per capita disposable income and the desire of the middle income group to live more lavishly, demand for sophisticated home textiles is growing in India and abroad. In fact this is one the largest textiles markets and comprises products made of both natural and synthetic fibres. Some of the products having great potential in this category include woven and knit wipes, such as cleaning wipes for domestic or commercial establishments; nonwoven wipes, viz. floor mops; tickings for filled items like cushions, duvets, pillows; skirt linings and other fabrics generally used for upholstery furniture and beddings; carpet and floor mats backings, dust cloths; sewing threads for different applications, etc.

Yet another important segment known as clothtech includes textile components and accessories used in manufacturing garments and other textile containing products. Items such as insulation materials, interlinings, sewing threads for various applications, labels, fasteners (zip and velcro), shoe laces, hooks and loop fasteners, etc. are in good demand.

There have been some recent developments in the area of technical textiles. Some of these are: breathable artificial fabrics, thin and light reflective fabrics, three dimensional (3-D) structured fabrics, metallic textiles, sports shoes, wearable computer jackets, warning vests, photonic textiles for innovative lighting solutions, wearable E-health systems, global 
positioning system (GPS) jackets, etc. These are likely to be popular in near future and offer new opportunities for product diversification.

\section{Industry Specific Actions}

The industry should offer best services to its existing clients, and look for new clients abroad, particularly in India's major markets in the EU and USA.

It is high time for the industry to relook at the product and service mix. Technical textiles are one area to be looked into for product diversification for both local and international markets.

The industry should follow up on business leads that are close to translating into deals, and if required, re-negotiate terms. This may require more frequent visits abroad for export promotion and materialization of export orders. Therefore, focus is needed on marketing efforts by participating in international trade fairs, exhibitions, and export promotion tours.

It is necessary to reduce or eliminate all non-value adding activities and re-engineer core processes to achieve cost efficiencies.

The industry should initiate research on new innovative products and services with higher perceptional value. Technical textiles offer new opportunities for innovations. Developing relationships with research institutions dealing with textiles is recommended.

The industry should go for fresh investments for technological upgradation to get economies of scale and avail of the technology upgradation fund scheme (TUFS) introduced by the government of India.

\section{Conclusion}

In spite of having historical comparative advantage, the Indian textile industry has been passing through turbulent times. Although it was envisaged that with the phasing out of MFAs, the country could become globally competitive, the gains could not be sustained. Further, global recession has added to existing crisis and million of jobs have been lost in this sector. For the industry's survival and revival, diversification into technical textiles can provide a forward momentum towards sustainable recovery because this segment will be about US\$ 15 billion in next two to three years and will account for about 10 per cent of 
global value. This will not only reduce the import of core technical textiles items into the country but will also boost significantly exports.

\section{References}

Arup, Rakshit; Hira, Manisha; and Ganopadhyay, U. K.(2007), “Technical Textiles: What India Need to do Now," http://www.sasmira.org/an\%20article.pdf, accessed on October 22, 2010.

ASSOCHAM (2010), "Eco Pulse: India Textile Scenario," http://www.fibre2fashion.com/ industry-article/21/2042/indias-textile-industry-still-spinning-a-gloomy-tale1.asp, accessed on November 14, 2010.

Business Co-ordination House ( $\mathrm{BCH}$ ) (2011), "About Technical Textiles," http://www.bch.in/about-technical-textiles.html, accessed on March 25, 2011.

China Daily (2009), "India's Textile Sector Faces Life or Death Struggle," http://www.chinadaily.com.cn/world/2009-01/20/content_7414600.htm, accessed on February 5, 2011.

Chugan, Pawan Kumar(2005), “Achieving Excellence in Textiles and Clothing Trade in Quota Free Regime: The Role of Human Resources" in Trivedi, Harismita (ed.), Achieving Competitive Advantage through People. New Delhi: Excel India Publishers, 112-33.

Chugan, Pawan Kumar (2006), "Micro and Macro Dynamics to be Globally Competitive in Quota Free Trade Regime: A Case of Indian Textiles and Clothing Industry," Abhigyan, 24(1), 2-15.

Chugan, Pawan Kumar (2007), “Technical Textiles: The Chinese Way to Excel in Post-Quota Regime and Strategy for Indian Industry" in Jain, R.K.; Gupta, Prashant; and Dhar, Upinder (eds.), Enhancing Enterprise Competitiveness: Strategy, Operations and Finance. Mumbai: Allied Publishers, $135-38$.

Chugan, Pawan Kumar (2011), "Technical Textiles: The Opportunities for Indian Textiles Industry in Turbulent Times" in Mehta, Bindi and Bhatt, Nityesh (eds.), Managing in Turbulent Times: Business Ecosystem and Macro Perspectives. New Delhi: Excel India Publishers, 494-509. 
Chugan, Pawan Kumar and Rawani, Meenakshi (2012), "Accelerating Human Resource Performance for Sustainable Growth: The Indian Textiles and Clothing Industry" in Pingle, Sameer and Chugan, Pawan Kumar (eds.) Global Recession to Global Recovery: Enhancing Enterprise Competitiveness through Human Capital and Operations Management. New Delhi: Excel India Publishers, 141-57.

FMAG (2009), “Downside Continues for Indian Textile Sector,” http://uk.fashionmag.com/ news-70710-Downside-continues-for-Indian-textile-sector, accessed on February 5, 2011.

FICCI (2008), "Study on Slowdown in India's Textile Industry,” retrieved from www.fiber2fashion.com.

Ghosal, Mousumi (2010), "Technical Textiles in India: Styling up New Approaches," http://www.expresstextile.com/cgi-bin/ecprint/MasterPFP.cgi?doc=, accessed on October 21, 2010.

ICRA (2009), Baseline Survey of Technical Textiles, a report prepared for the Textiles Commissioner, Government of India, http://technotex.gov.in/Revised_Final_Report__Baseline_Survey_of_Technical_Textile\%2oindustry_in_India.pdf, accessed on October 22, 2010.

Jayaramiah, Jaishankar (2009), "Recession Forces Textile Sector to take IT Route," Financial Express, July 6, http://www.financialexpress.com/news/recession-forces-textile-sector-totake-it-route/485348/o, accessed on March 31, 2011.

Kannan, Suresh (2008), "Technical Textiles has Tremendous Growth Scope in India - SRF," http://www.fibre2fashion.com/news/company-news/srf limited/newsdetails.aspx?news_id = 67020, accessed on October 21, 2010 .

Mehta, Shramana Ganguly (2011), "India Now Stitching Clothes for Developing Economies," Economic Times, October 20.

Mital, Reena ; Swaminathan, Sudha; and Dogra, Sapna (2005), "Will India become Manufacturing Base for Technical Textiles: Cover Story," http://www.expresstextile.com/ 20050515 / coverstory01.shtml, accessed on November 10, 2010.

Parsoli Corporation Ltd. (PCL) (2010), “Textile Industry,” http://www.islamicequity.co.in/ pdf/textile.pdf, accessed on October 22, 2010. 
Sheshadri, Ramkumar (2008), "India's Technical Textiles Sector Set to Boom," http://www.rediff.com/money/2008/jul/23textile.htm accessed on October 21, 2010.

Sheshadri, Ramkumar (2009), "Nonwovens for Value-added and Defense Applications," http://www.nonwovensupplier.com/articledetails.aspx?articleid=1538\&page=1, accessed on October 22, 2010.

Sheshadri, Ramkumar (2010), "Technical Textiles: A Growing Necessity for the Indian Textile Industry," http://www.technicaltextile.net/articles/nonwoven-textiles/ detail.aspx ?articleid $=3178 \&$ pageno $=4$, accessed on October 21, 2010.

Sheshadri, Ramkumar and Appachi, Arunachalam (2010), "India: Rising Opportunities in Nonwovens and Technical Textiles," http://www.fibre2fashion.com/industryarticle/pdffiles/9/819.pdf?PDFPTOKEN=1136c5d3a46ff2a176120140b4326281aacb5a52|12 86955290\#PDFP, accessed on October 21, 2010.

Thakurta, Paranjoy Guha (2009), “Meltdown Hits Textile Idustry,” http://ipsnews.net/ ews.asp?idnews=45630, accessed on February 5, 2011. 
